Available online at https://jurnal.stmikroyal.ac.id/index.php/jurdimas

\title{
PELATIHAN KERAJINAN TANGAN DALAM UPAYA MEMANFAATKAN PELUANG BISNIS DI ERA PANDEMI
}

\author{
Try Wulandari ${ }^{{ }^{*}}$, Emilda ${ }^{1}$, Shafiera Lazuarni ${ }^{1}$ \\ ${ }^{1}$ Program Studi Manajemen, Universitas Indo Global Mandiri \\ email:wulan@uigm.ac.id
}

\begin{abstract}
The COVID-19 outbreak, which has been going on for about a year and a half, continues to harm the people and the Indonesian economy. Indonesia's economic activity is getting weaker and lowering the purchasing power of the Indonesian people. One of the prevention strategies implemented by the government is by limiting community mobility through work from home and also study from home for students. Since the enactment of this policy, students have more free time at home. Therefore, this PKM activity aims to introduce business opportunities that can be utilized by students. This free handicraft training hopes that the participants will maximize the training in making handicrafts and earn additional income during the pandemic. The target of this activity is students. Based on the results of the work made by the participants, this PKM activity can be said because the participants succeeded in making their respective works well in the first try. The handicrafts made have also met the expectations of the PKM team and can be said to be worthy of sale.
\end{abstract}

Keywords: business opportunity, handicraft, mask connector

\begin{abstract}
Abstrak: Wabah covid-19 yang sudah berlangsung kurang lebih satu setengah tahun terakhir ini terus merugikan masyarakat dan perekonomian Indonesia. Aktivitas perekonomian Indonesia kian melemah dan menurunkan daya beli masyarakat Indonesia. Salah satu strategi pencegahan yang diterapkan oleh pemerintah yaitu dengan cara membatasi mobilitas masyarakat melalui work from home dan juga study from home bagi para mahasiswa. Sejak diberlakukannya kebijakan ini, para mahasiswa memiliki lebih banyak waktu luang di rumah. Oleh karena itu, kegiatan PKM ini bertujuan untuk mengenalkan peluang bisnis yang dapat dimanfaatkan oleh para mahasiswa. Pelatihan kerajinan tangan yang diberikan secara gratis ini mengharapkan para peserta nantinya akan memaksimalkan pelatihan membuat kerajinan tangan dan meraih penghasilan tambahan selama pandemi. Sasaran kegiatan ini adalah para mahasiswa. Berdasarkan hasil karya yang dibuat oleh para peserta, kegiatan PKM ini dapat dikatakan karena para peserta berhasil membuat karyanya masing-masing dengan baik dalam percobaan pertama. Hasil kerajinan tangan yang dibuat pun sudah memenuhi harapan tim PKM dan dapat dikatakan layak untuk dijual.
\end{abstract}

Kata kunci: kerajinan tangan; konektor masker; peluang bisnis 
Available online at https://jurnal.stmikroyal.ac.id/index.php/jurdimas

\section{PENDAHULUAN}

Wabah pandemi virus covid-19 sudah berlangsung selama satu setengah tahun. Jumlah masyarakat yang terpapar virus ini pun kian meningkat, terlebih lagi di Indonesia. Wabah pandemi ini pun terjadi hamper diseluruh negara di dunia. Organisasi WHO (world health organization) juga sudah mengeluarkan pernyataan bahwa pandemi covid-19 ini termasuk dalam keadaan darurat kesehatan global (Darmayanti, Mildawati, \& Susilowati, 2021).

Dilansir dari kompas.com, per tanggal 22 mei kasus positif bertambah 5.296 sehingga total pasien menjadi 1.769.940 orang. Angka yang terus bertambah ini tentunya menjadi perhatian utama pemerintah dan berbagai upaya dilakukan oleh pemerintah untuk memutuskan rantai penyebaran virus. Salah satu upaya yang dihimbau oleh pemerintah adalah social distancing yaitu menjaga jarak minimal satu meter juga menghindari kerumunan masyarakat. Strategi ini juga dipertegas dengan himbauan untuk berkegiatan dari rumah, dimulai dari sekolah, berkerja hingga beribadah.

Seiringnya dengan work from home diterapkan, kini masyarakat lebih banyak waktu menghabiskan waktu di rumah dan memiliki waktu luang dikarenakan jadwal bekerja yang lebih fleksibel. Begitu pula dengan para mahasiswa, dengan tidak diperbolehkan untuk berkegiatan di lingkungan kampus. Apabila umumnya, mahasiswa dapat berkumpul untuk belajar kelompok, kegiatan ekstrakulikuler, kegiatan organisasi atau berkegiatan sosial lainnya, kini mahasiswa banyak memiliki waktu luang di rumah masing-masing.

Memiliki waktu senggang pada saat pandemi mungkin dapat menjadi hal baik bagi para pekerja atau mahasiswa namun tidak bagi para pelaku bisnis. Adanya penerapan social distancing menyebabkan sedikitnya jumlah konsumen yang berkunjung ke toko-toko. Hal ini tentunya meresahkan bagi para pelaku bisnis, terlebih lagi para pelaku bisnis yang kurang paham teknologi dan tidak familiar dengan strategi pemasaran online.

Menurut ekonom Institute for Development of Economics and Finance (INDEF), Bhima Yudistira, rendahnya aktivitas ekonomi selama pandemi menekan daya beli masyarakat dan menurunkan PMI manufaktur menjadi 50,9 di bulan Februari 2021 dari semula 52,2 di bulan Januari 2021. Hal ini menunjukkan bahwa Indonesia sedang dalam masa resesi. Lebih lanjut dijelaskan bahwa sejak terserang covid-19, ekonomi Indonesia anjlok hingga $-5.32 \%$ di kuartal kedua tahun 2020. Perbaikan yang terjadi berhasil menurun menjadi $3.49 \%$ namun tetap saja masih berada di zona negative (Anggraini, 2021).

Merosotnya pertumbuhan ekonomi akibat virus corona ini pun tidak hanya dirasakan di Indonesia namun juga secara global. Hal ini tercerminkan dari anjloknya harga saham global dan di Indonesia. Lebih parahnya, angka penurunan kali ini merupakan angka terendah bahkan bila dibandingkan dengan pada saat terjadinya peristiwa wabah penyakit menular yang pernah terjadi sebelumnya (Mangindaan, 2020).

Waktu luang yang dimiliki oleh para pekerja ataupun para mahasiswa dapat menjadi peluang bisnis yang dimanfaatkan yang nantinya juga dapat membantu perekonomian Indonesia (Putri, 2021). Seperti yang diketahui, pemakaian masker menjadi hal wajib yang harus selalu dipatuhi masyarakat. Menjual masker pun menjadi salah satu 
pekerjaan sampingan yang banyak dilakukan saat ini. Tidak hanya itu, beberapa aksesoris pelengkap masker pun dapat menjadi peluang bisnis yang menarik. Salah satunya ada penghubung masker atau mask connector yang ditujukan bagi para hijabers dalam menggunakan masker earloop atau masker yang dicantolkan di telinga (Lasafta, 2021). Oleh karena itu, kegiatan pengabdian kepada masyarakat kali ini bertujuan untuk membantu para mahasiswa memanfaatkan waktu luang yang dimiliki untuk berbisnis aksesoris penghubung masker. Melalui kegiatan PKM ini, para mahasiswa juga diharapkan dapat meningkatkan soft skills melalui pelatihan kerajinan tangan ini.

Hasil yang diharapkan dari kegiatan PKM ini yaitu para peserta akan mampu membuat penghubung masker yang memiliki nilai jual dan kualias yang baik. Setelah diadakan kegiatan ini pula, diharapkan para peserta dapat menambah penghasilan pribadinya untuk dapat bertahan di masa pandemi ini.

\section{METODE}

Metode yang akan digunakan pada kegiatan PKM ini ialah metode pelatihan. Definisi dari pelatihan itu sendiri yaitu kegiatan yang melibatkan kegiatan yang disertai dengan cara menunjukkan langsung dan pengoperasian sistem atau peralatan (Morelli, 2015). Selain itu, akan diberikan beberapa prosedur tahapan untuk mendukung keberhasilan kegiatan adalah persiapan, pelaksanaan kegiatan dan tinjuan pelaksanaan (Aisyah \& Kurniawati, 2019).

Tahap pertama yang akan dilakukan adalah mempersiapkan tim kegiatan PKM, pengecheckan lokasi mitra lalu menyiapkan semua bahan dan peralatan yang dibutuhkan, pelaksanaan kegiatan, penilaian kegiatan hingga pembuatan laopran kegiatan PKM. Tim kegiatan ditentukan terlebih dahulu untuk memilih ketua dan anggota tim serta tugas dan tanggung jawab masingmasing anggota tim. Selain itu, jadwal pelaksanaan dan jadwal pengamatan lokasi mitra juga ditentukan pada tahapan ini.

Setelah itu, tahapan selanjutnya adalah peninjauan lokasi kegiatan akan berlangsung. Hal ini penting diperhatikan dan dipersiapkan terlebih dahulu mengingat keadaan pandemic dan peraturanperaturan protokol kesehatan yang perlu ditaati. Adapun beberapa kriteria lokasi yang perlu diperhatikan adalah lokasi yang tidak terlalu ramai, lokasi memiliki ruangan outdoor dan juga menyediakan tempat cuci tangan dan hand sanitizer gratis untuk para pengunjung.

\section{PEMBAHASAN}

\section{Persiapan Memilih Lokasi Pelatihan}

Sesuai dengan kondisi pandemi saat ini, maka pemilihan lokasi pelatihan menjadi lebih selektif. Kriteria-kriteria yang sudah disebutkan sebelumnya menjadi bahan pertimbangan yang utama dalam tahap ini. Kriteria yang pertama yaitu lokasi pelatihan bukan tempat yang ramai sehingga jauh dari kerumunan masyarakat. Kedua, lokasi pelatihan harus menyediakan tempat cuci tangan dan hand sanitizer gratis bagi konsumen sehingga akan lebih memudahkan pembeli untuk membersihkan tangannya. Ketiga, lokasi yang dipilih sebaiknya memiliki lokasi diluar ruangan atau outdoor agar para peserta tidak berada di suatu ruangan yang sama untuk waktu yang lama. Berdasarkan beberapa pertimbangan itu- 
lah, maka tim sepakat untuk memilih Restoran New Town Kopitiam sebagai tempat pelatihan membuat kerajinan tangan kali ini.

\section{Persiapan Membuat Kerajinan Tan- gan}

Sebelum kegiatan PKM dilakukan, tim menyiapkan bahan-bahan yang dibutuhkan seperti dapat dilihat pada Gambar 1. Penghubung masker yang akan dibuat pada kegiatan PKM adalah yang berbahan dasar manik-manik atau ceko. Oleh karena itu, anggota tim memilih ceko yang akan digunakan dengan pertimbangan warna, bentuk hingga ukuran ceko yang akan digunakan.

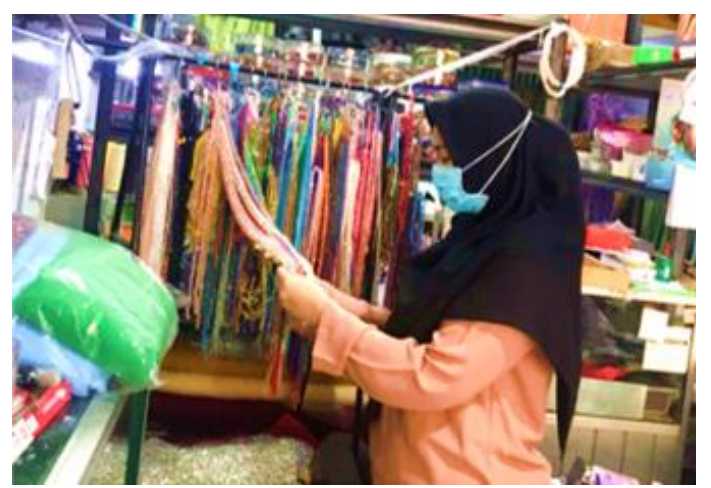

Gambar 1. Anggota tim sedang memilih ceko

Bahan utama yang diperlukan adalah ceko atau biasa juga disebut manik-manik. Bahan ini bisa dibeli pada toko-toko khusus yang menjual pernak Pernik menjahit atau memayet. Toko yang dikunjungi oleh tim PKM pada gambar 1 diatas berada di jalan dempo, Kota Palembang. Selain ceko, ada juga beberapa bahan yang diperlukan, seperti senar pancing, ring kecil, kokot udang, stopper kodokan, dan juga kokot udang (lihat Gambar 2). Semua bahan ini juga bisa dibeli ditoko yang sama, Toko Maria Feeling.
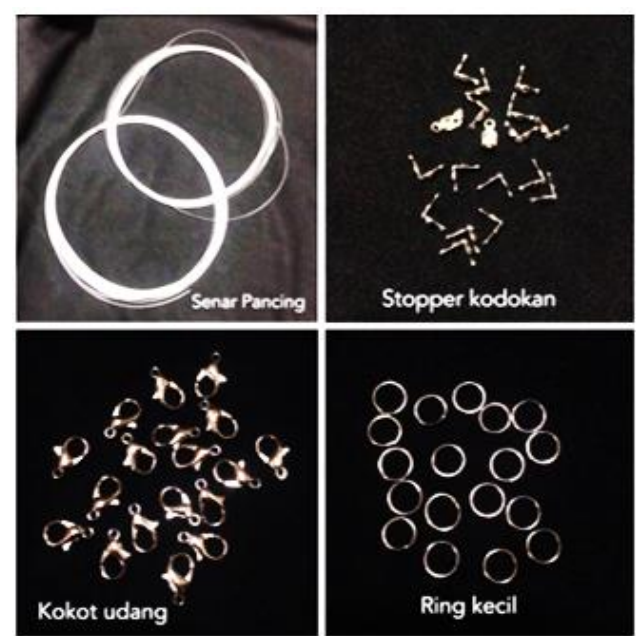

Gambar 2. Alat-alat pelengkap untuk membuat konektor masker

\section{Pemaparan materi Pelaksanaan Pelatihan Kerajinan Tangan}

Sebelum mahasiswa diajak untuk praktek sendiri, para mahasiswa diberikan materi terlebih dahulu. Materi-materi yang akan disampaikan oleh Try Wulandari, S.E., M.Fin selaku pemateri adalah penjelasan alat-alat dan bahanbahan yang akan digunakan, manfaat dari membuat kerajinan tangan penghubung masker sebagai peluang bisnis, jenisjenis penghubung masker, kemudian dilakukan demonstrasi membuat kerajinan tangan penghubung masker.

\section{Pelatihan Praktek Langsung}

Setelah semua materi dipaparkan, para mahasiswa diberikan bahan dan alat masing-masing untuk mulai mencoba membuat kerajinan tangan sendiri. Selama pelatihan praktek langsung ini berjalan, tim tetap memperhatikan dan membimbing para peserta. Selama praktek berlangsung, semua peserta dan tim PKM tetap mematuhi protokol Kesehatan seperti tetap memakai masker, menjaga jarak dengan peserta yang lain dan mencuci tangan sebelum dan setelah kegiatan. Berikut beberapa foto dokumentasi selama kegiatan berlangsung. 
Jurdimas (Jurnal Pengabdian Kepada Masyarakat) Royal

Vol. 4 No. 3, September 2021, hlm. 281 - 286

ISSN 2614-7912 (Print)

DOI: https://doi.org/10.33330/jurdimas.v4i3.1196

ISSN 2622-3813 (Online)

Available online at https://jurnal.stmikroyal.ac.id/index.php/jurdimas

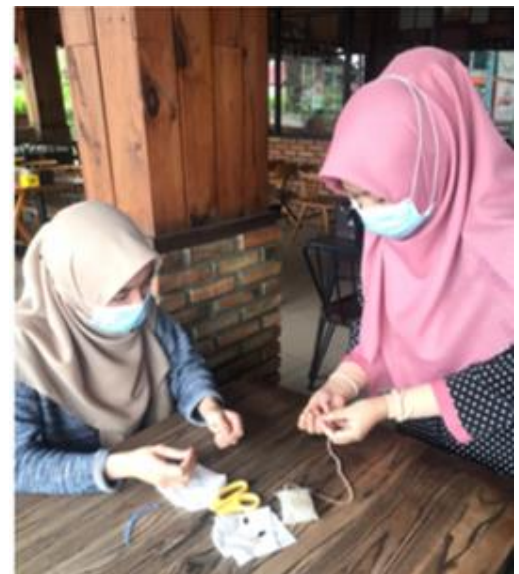

Gambar 3. Ketua tim PKM memberikan pelatihan kepada peserta

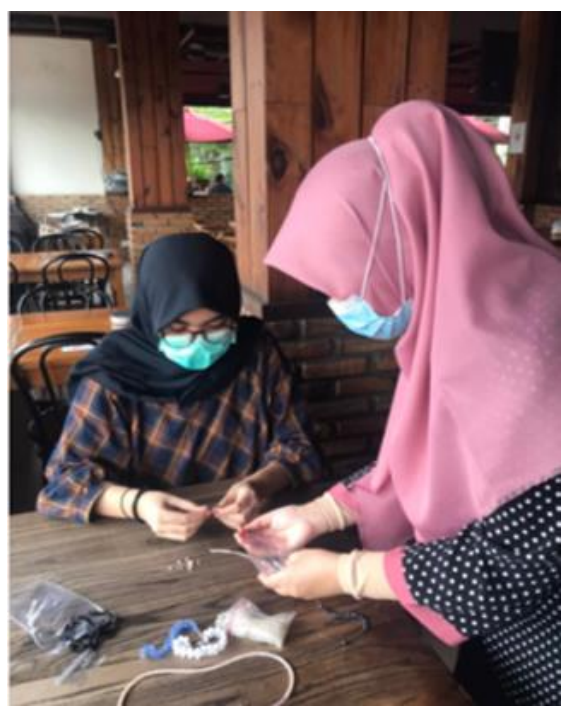

Gambar 4. Ketua tim PKM sedang mengecheck hasil karya peserta

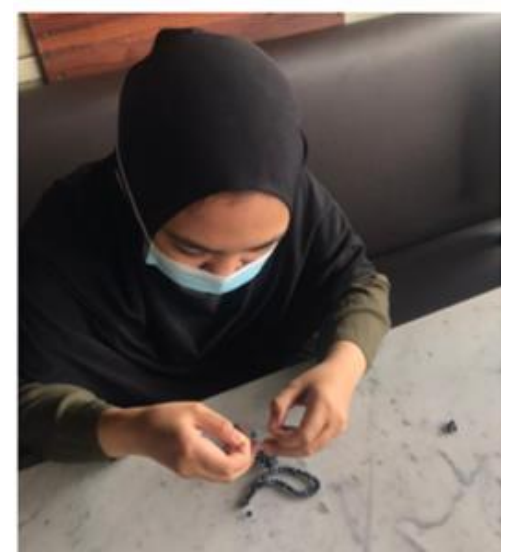

Gambar 5. Para peserta sedang praktek langsung membuat penghubung masker

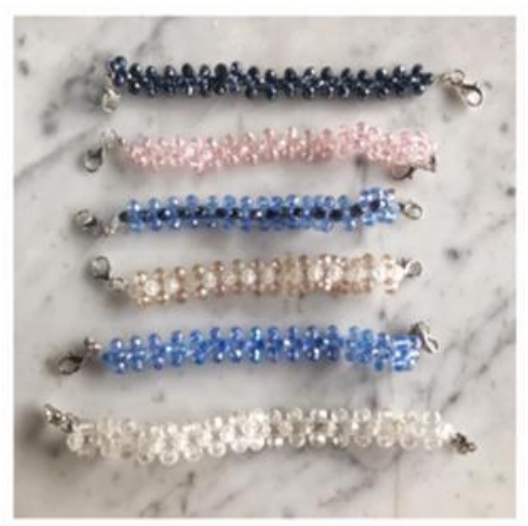

Gambar 6. Beberapa hasil kerajinan tangan para peserta

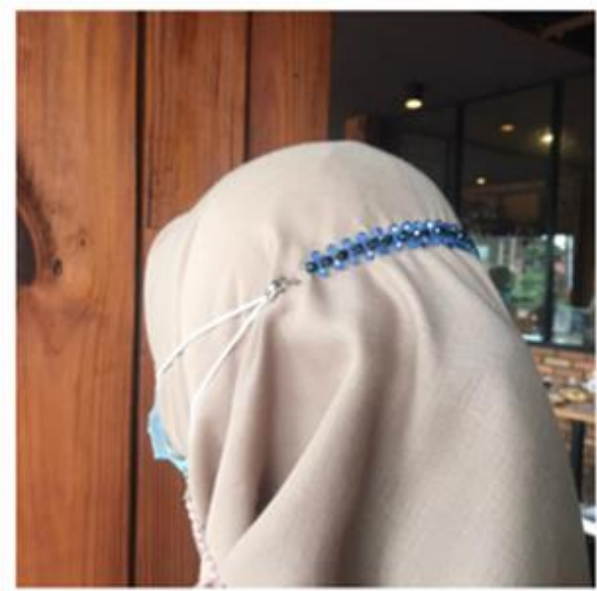

Gambar 7. Contoh pemakaian hasil kerajinan tangan oleh peserta

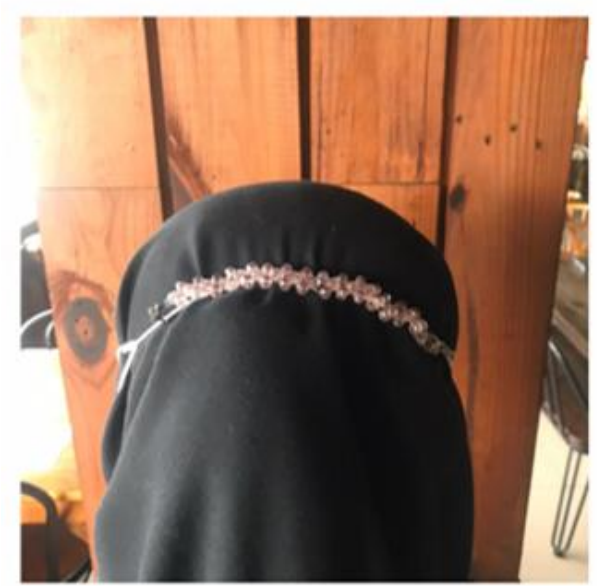

Gambar 8. Contoh pemakaian hasil kerajinan tangan oleh peserta 


\section{SIMPULAN}

Kegiatan PkM ini bertujuan untuk memberikan pelatihan kerajinan tangan kepada para mahasiswa di Kota Palembang dengan harapan dapat dijadikan sumber penghasilan tambahan bagi para mahasiswa. Berdasarkan data feedback yang diterima oleh tim kegiatan ini melalui sesi tanya jawab, dapat disimpulkan bahwa kegiatan berjalan dengan lancar dan sukses. Hal ini dicerminkan dari jawaban-jawaban para peserta dimana mayoritas dari peserta setuju bahwa pelatihan ini memberikan informasi dan ilmu baru bagi mereka dibidang kerajinan tangan. Melihat hasil kerajinan tangan para mahasiswa yang memuaskan pada percobaan pertama, para mahasiswa terdorong dan tertarik untuk mulai memulai usaha jual beli penghubung masker ini. Hasil kerajinan tangan yang dihasilkan juga sudah layak untuk diperjual belikan. Sehingga dapat disimpulkan bahwa tujuan dari kegiatan PkM ini terpenuhi. Selain itu, para peserta juga merasa bahwa proses pembuatan kerajinan tangan ini tidak terlalu rumit untuk dilakukan dan ditekuni sebagai bisnis.

\section{DAFTAR PUSTAKA}

Aisyah, S., \& Kurniawati. (2019). PKM keterampilan menjahit pada remaja putri di Desa Bonto Jai Kecamatan Bissapu Kabupaten Bantaeng. Prosiding Seminar Nasional, 1-4.

Anggraini, M. (2021). 5 Peluang Usaha Saat Pandemi, Ciptakan Pundipundi Rupiah | merdeka.com.

Darmayanti, N., Mildawati, T., \& Dwi Susilowati, F. (2021). Dampak
Covid-19 Terhadap Perubahan Harga Dan Return Saham. EKUITAS (Jurnal Ekonomi Dan Keuangan), 4(4), 462-480. doi: 10.24034/j25485024.y2020.v4.i 4.4624

Emilda, E., Wulandari, T., \& Lazuarni, S. (2021). Pelatihan Keterampilan Menjahit Masker Kain Dalam Memanfaatkan Peluang Bisnis Era Pandemi Covid-19. Jurdimas (Jurnal Pengabdian Kepada Masyarakat) Royal, 4(2), 111-120.

Lasafta, D. I. (2021). Tali masker Archives - Info Bisnis dan Keuangan.

Mangindaan, J. V. (2020). Analisis Perbandingan Harga Saham PT Garuda Indonesia Persero (Tbk.) Sebelum dan Sesudah Pandemi Covid-19. Jurnal Administrasi Bisnis (Jab), 10(2), 80-85. doi: 10.35797/jab.10.2.2020.31281.8 $0-85$

Morelli, N. (2015). Challenges in designing and scaling up community services. The Design Journal, 18(2), 269-290. doi: doi.org/10.2752/175630615X14 212498964394

Putri, I. (2021). 5 Produk dan Peluang Bisnis yang Diprediksi Jadi Tren 2021.

Vuspitasari, B. K., Deffrinica, D., Siahaan, S. V. B., \& Novita, N. (2021). Pemberdayaan Perempuan dalam Memanfaatkan Sampah Kresek Menjadi Produk Bernilai Ekonomis. Jurdimas (Jurnal Pengabdian Kepada Masyarakat) Royal, 4(1), 33-38. 